\title{
Quantitative differences in the chemoreceptor systems in the barbels of two species of Mullidae (Mullus surmuletus and M. barbatus) with different bottom habitats
}

\author{
Antoni Lombarte, Hugo Aguirre \\ Institut de Cí̀ncies del Mar (CSIC), Passeig Joan de Borbó s/n, E-08039 Barcelona, Catalonia, Spain
}

\begin{abstract}
Qualitative and quantitative observations were made of the growth, distribution and density of external taste buds (TB) in the barbels of 2 phylogenetically close species of the Mullidae family (Perciformes: Teleostei) from the NW Mediterranean. Both species live on the continental shelf and have similar benthivorous feeding habits, but each prefers a different bottom habitat. Mullus surmuletus is typical of sandy and rocky bottoms, while Mullus barbatus is found over muddy bottoms and reaches to deeper waters than $M$. surmuletus. The barbels of $M$. barbatus differ from those of $M$. surmuletus in that they have a greater density and number of TBs, which are characteristically distributed in well-defined groups. These characteristics of M. barbatus are assaciated with a greater sensitivity to chemical stimuli, as there is a compensatory relationship with the reduction of the visual field which occurs in muddy and deeper waters.
\end{abstract}

KEY WORDS: Ecomorphology - Taste buds Barbels Mullus barbatus Mullus surmuletus

\section{INTRODUCTION}

The comparative study of morphological characteristics and their relationship to environmental parameters is important for the understanding of interactions between organisms and their environment (Norton et al. 1995). Since organisms recelve information from the environment in the form of stimuli (chemical, mechanical, luminous, electrical, etc.) through sense organs, the study of the latter is essential to explaining the mechanisms that regulate animals' distribution in space and time (Blaxter 1988) and the phenomena of competition and predation (Gomahr et al. 1992).

In ecomorphological studies of the sense organs of teleost fishes, the relationships between patterns of morphological diversity of the chemosensory systems and patterns of ecological diversity have been little studied (Norton et al. 1995). Only recently have investigations of these systems begun, mainly with fresh-water ostariophysi (Gomahr et al. 1992, Huber \& Rylander 1992, Cambray 1994, Kotrschal 1995).
These studies compared the morphology of species which are phylogenetically close, but display varied ecological characteristics. Less is known of the relationships between the morphology of the chemoreceptors and the environment in marine non-ostariophysi teleosts. Studies have focused on solitary chemosensory cells (Kotrschal 1992, 1995), the sensory pores of the dorsal radii of Pleuronectiformes (Appelbaum et al. 1983, Livingston 1987), and recently on the hyoid barbels of the Mullidae family (McCormick 1993).

The objectives of this study were to examine the chemoreceptor structure of the barbels in 2 species living in different environments, in order to contribute new data about the adaptation of the chemosensory system to trophic resources in different substrata, and to complement existing knowledge of the development and changes in the barbel's structure in larval and juvenile fish stages (McCormick 1993) with a quantitative study of their development in the post-settlement period. Up to now there have been no data on the 
growth of chemoreceptor cells over a lengthy period of a teleostean fish's life

These objectives are tackled in this study of the taste buds in the hyoid barbels of red mullet Mullus barbatus and striped red mullet Mullus surmuletus, phylogenetically closely related species which live in the NE Atlantic and Mediterranean (Gosline 1984, Hureau 1986). The barbels of the Mullidae arise from the transformation of the branchiostegal ray into a fleshy, flexible appendage covered with sensory structures (Bougis 1952, Gosline 1984, McCormick 1993, Lombarte \& Aguirre 1995). These specialised barbels provide a base from which the Mullidae have evolved their ecological and evolutionary features which assist them in recognising the bottom and in searching for prey items (Gosline 1984, McCormick 1993). In the genus Mullus the ultrastructure of the TB corresponds to that described for other teleost fish (Lombarte \& Aguirre 1995) and is characterised by a pore, the surface of which is composed of the apical endings of different chemoreceptor cells with large and small microvilli. These cells are surrounded by non-sensorial marginal cells (Caprio 1988, McCormick 1993, Reutter 1994).

Given the commercial importance of the 2 species of Mullus selected, various aspects of their biology have been widely studied (spawning, settlement, growth, feeding). Even though their distributions overlap, they show a clear segregation in habitat. $M$. surmuletus is adapted to broken and rough ground and its maximum abundance is located in depths of less than $100 \mathrm{~m}$, whereas $M$. barbatus inhabits muddy bottoms and maximum abundance of adults occurs at greater depths (between 100 and $300 \mathrm{~m}$ ). In highly sedimentary areas such as river mouths, $M$. barbatus may be found at lesser depths and exclusively. It has also been found that spawning and recruitment of the 2 species in the Mediterranen are separated in time (Bougis 1952, Suau \& Vives 1957, Hureau 1986, Reñones et al. 1995) and in space (García-Rubies \& Macpherson 1995, Sánchez et al. 1995)

\section{MATERIAL AND METHODS}

Scanning electron microscope (SEM) analyses of the barbel surface were performed on right-side barbels of 16 specimens of Mullus barbatus $(58$ to $227 \mathrm{~mm}$ in total length) and 15 specimens of $M$. surmuletus (56 to $287 \mathrm{~mm}$ in total length).

The sizes cover a long period in the life of these fish from their settlement period on the bottom to maturity. Specimens were collected using oceanographic and commercial fishing boats in the northwestern Mediterranean.
The barbels were prepared for SEM observation in accordance with a standard protocol for observing the surface of sense organs (Popper 1977, Kotrschal 1992). As soon as the specimens came on deck, total length was measured (TL in $\mathrm{mm}$ ), as were barbel length and basal diameter (BL and BD in mm respectively, Fig. 1). The barbels were fixed in a solution of filtered $2.5 \%$ glutaraldehyde in $0.2 \mathrm{M}$ phosphate buffer. Tissues were postfixed in $1 \%$ osmium tetroxide, dehydrated and dried by the critical point method. The samples were mounted on aluminium stubs, coated with gold and viewed with a Hitachi S 570 SEM operating at $15 \mathrm{kV}$.

To find the mean density of the taste buds (dTB), the total number of taste buds (nTB) and their distribution patterns of the taste buds, photographs were taken at between $300 \times$ and $500 \times$ at 6 points distributed along the barbel (Fig. 2). From these photographs, dTB was calculated (number TB $\mathrm{mm}^{-2}$ ) for each barbel, as well as the number of TBs per group.

Barbel surface area (BS) was considered as that of a cone (the basal radius $(\mathrm{Br})$ and length (BL) of which correspond to those of the barbel), and was calculated according to the following formula

$$
\mathrm{BS}=\pi \cdot \mathrm{Br} \cdot \sqrt{\mathrm{Br}^{2}+\mathrm{BL}^{2}}
$$

The total number of TBs (nTB) was calculated from the barbel area and mean density of the TBs:

$$
\mathrm{nTB}=2 \cdot \mathrm{dTB} \cdot \mathrm{BS}
$$

Allometrical relationships between TL and BS, dTB and $\mathrm{nTB}$ were determined by fitting a power equation, $Y=a X^{b}$, for each size relationship. This resulted in high correlations, with values of $\mathrm{r}^{2}$ between 0.79 and 0.98 . Analysis of covariance was used to compare the curves of the morphometric relationships between the 2 species and the $t$-test was used to compare the slope value to the hypothetical value of isometry. The confidence limits for parameter $b$ (slope) were also calculated for the $95 \%$ level of significance.

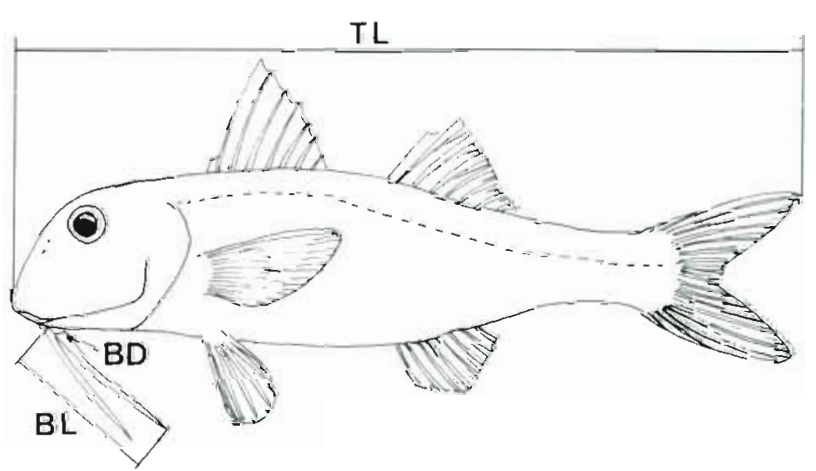

Fig. 1. Measurements taken in Mullus surmuletus and $M$ barbatus. TL: total length of the fish body; BL: barbel length; and BD: barbel basal diameter 


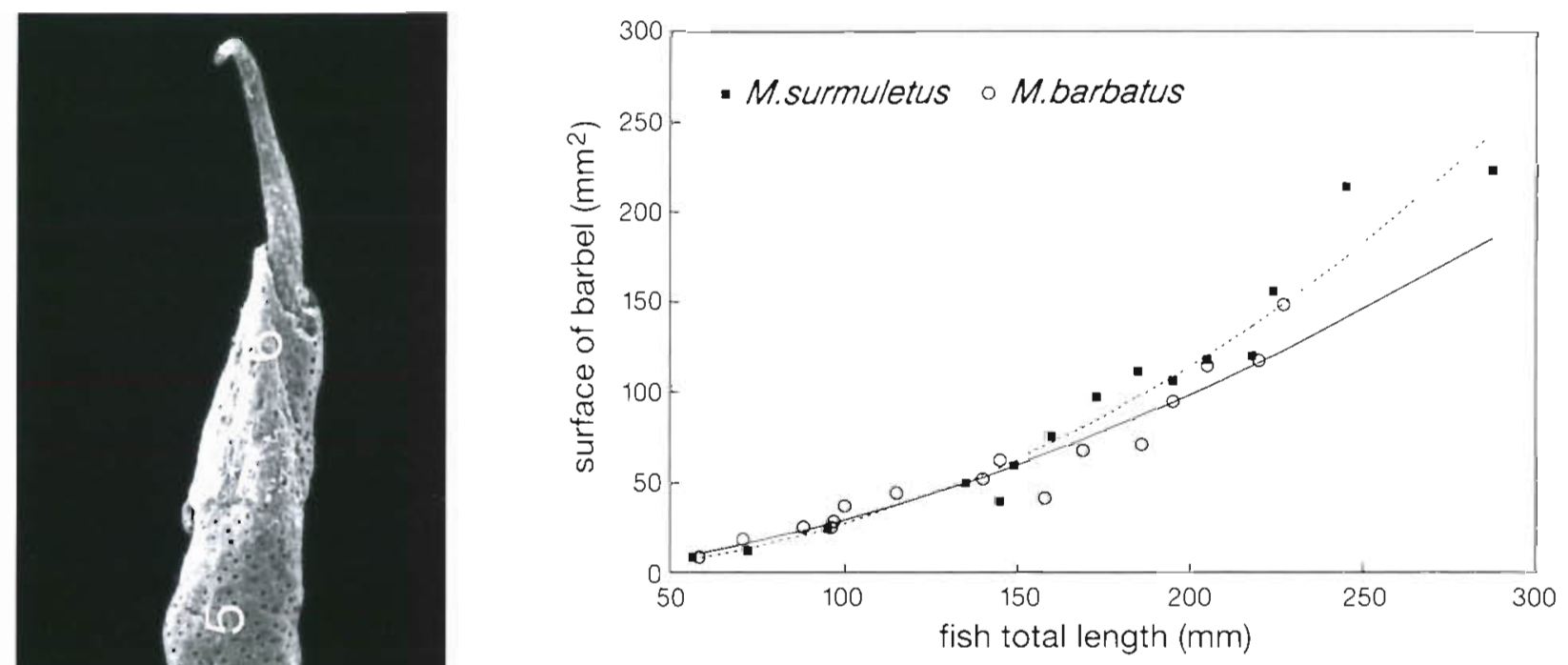

Fig. 3. Relationship between barbel surface area $\left(B S, \mathrm{~mm}^{2}\right.$ ) and total length of fish (TL, $\mathrm{mm})$ in Mullus surmuletus (----) and M. barbatus ( $\longrightarrow$

\section{RESULTS}

\section{Growth of the barbel surface}

Both species showed a growth in barbel surface (BS) during post-larval growth (Fig. 3). In Mullus surmuletus the growth relationship was $\mathrm{BS}\left(\mathrm{mm}^{2}\right)=0.017 \mathrm{TL}$ $(\mathrm{mm})^{2.097}$ This growth was characterised by its isometric relationship to total fish length $(b=2.097 \pm$ $0.134, t=1.238)$. M. barbatus, however, showed the growth relationship BS $\left(\mathrm{mm}^{2}\right)=0.009 \mathrm{TL}(\mathrm{mm})^{1.754}$. This growth was allometrically negative $(b=1.754 \pm 0.078$, $t=1.830, p<0.05$ ). The slopes were tested for isometry against a value of $b=2$, as the relationship was between a linear value and a surface value. Comparison of the slopes $(b)$ showed that the relative size of the barbel surface area was greater in $M$. surmuletus than in $M$. barbatus $(t=2.35, \mathrm{p}<0.05)$. These differences were more apparent in adults with lengths in excess of $140 \mathrm{~mm}$.

\section{Taste bud distribution pattern differences}

The surfaces of the barbels were completely covered with TB. The 2 species were well differentiated in the distribution of the chemoreceptor cells. The TB were present in isolation or in groups. Between the species there were clear differences in TB grouping. Mullus surmuletus had sensory cells sparsely distributed along the surface of the barbel (Fig. 4a), unlike M. barbatus which had sensory cells in well-defined groups (Fig. $4 \mathrm{~b}$ ).

These differences were clearly observed in quantitative comparison (Fig. 5). Mullus surmuletus had a high 


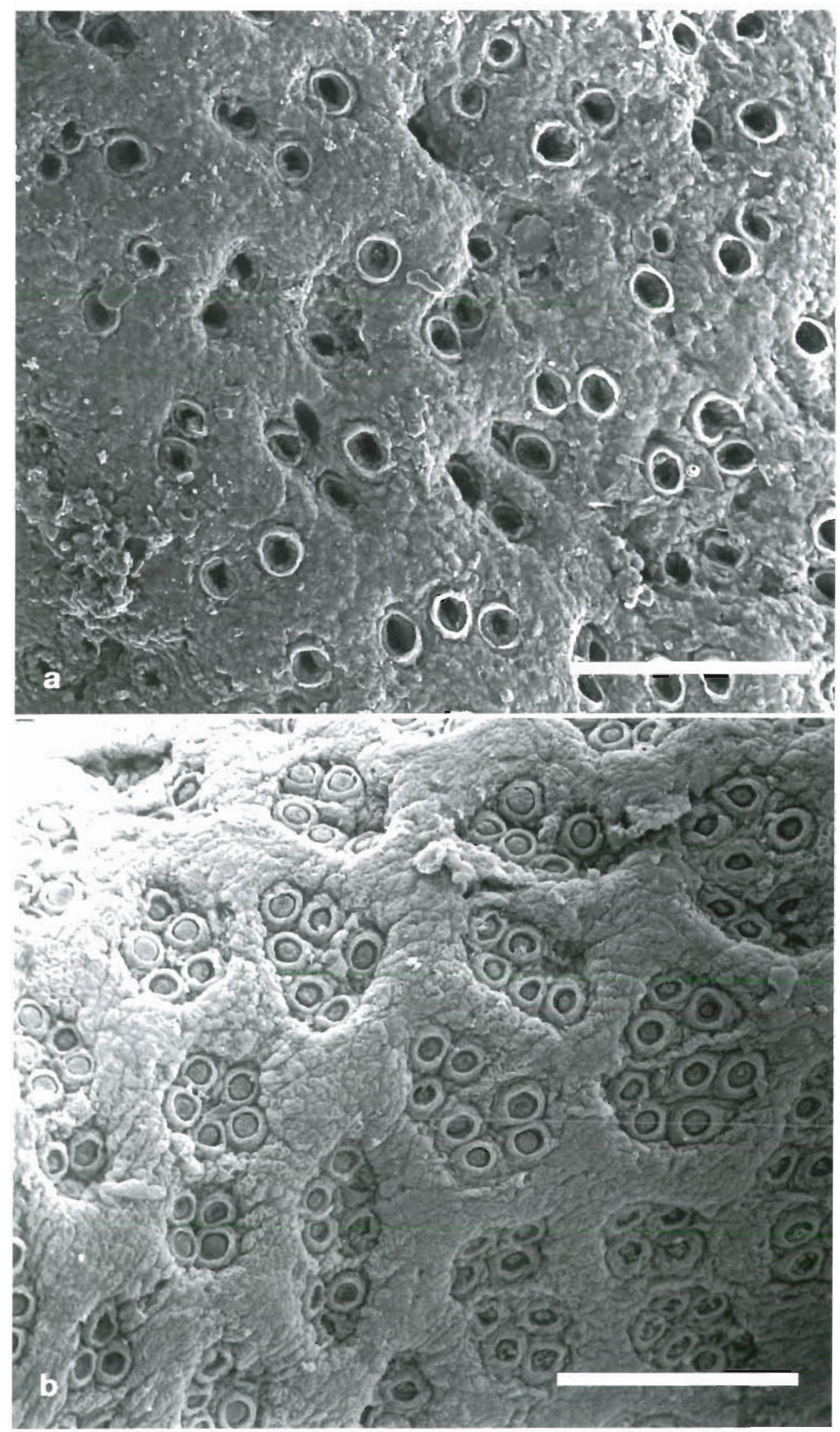

Fig. 4. Distribution of taste buds in (a) Mullus surmuletus, (b) M. barbatus. Scale bars $=200 \mu \mathrm{m}$ 


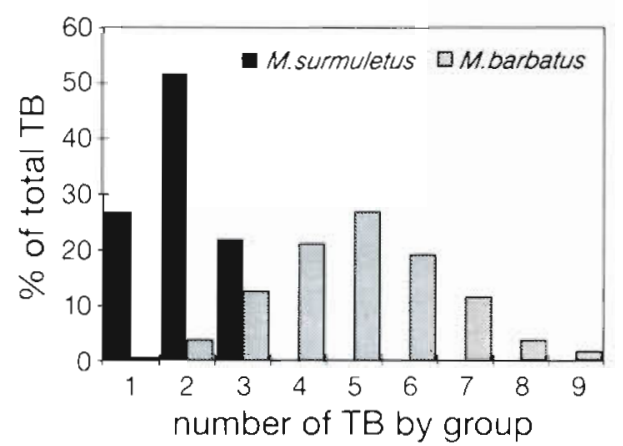

Fig. 5. Mullus surmuletus and $M$. barbatus. Grouping of taste buds (TB). Colums show percentage of TB in groups of various sizes mm specimen. $M$. barbatus had a similar large increase, $\mathrm{NTB}=403.991 \mathrm{TL}(\mathrm{mm})^{036}$, growing from $12664 \mathrm{~TB}$ in a $58 \mathrm{~mm}$ specimen to $56767 \mathrm{~TB}$ at $227 \mathrm{~mm}$. In both species the growth in the number of TB showed a negative allometric relationship to growth in the length of the fish. For $M$. surmuletus, $b=$ $1.238 \pm 0.214, t=3.561$ and for $M$. barbatus, $b=0.936 \pm$ $0.1474, t=7.222$.

As with density, differences were observed between the covariances of the curves of the 2 species $(f=$ $14.14, p>0.05)$. These differences showed a higher number of TBs in Mullus barbatus than in $M$. surmuletus percentage of TBs in isolation $(26.7 \%)$ or in groups of 2 or $3 . M$. barbatus showed TB groups with larger numbers (2 to 9), with 5 being the most common number per group $(26.6 \%)$. Isolated TB were very scarce $(0.6 \%$ of the total), unlike in M. surmuletus.

\section{Density of taste buds}

Both species showed a reduction in TB density (Fig. 6) in relation to the length of the specimen (dTB) throughout growth, expressed as a power equation with a negative exponent. In Mullus surmuletus this relationship was $\operatorname{dTB}\left(\mathrm{mm}^{2}\right)=$ $13918.86 \mathrm{TL}(\mathrm{mm})^{-0.859}$, and in $M$. barbatus it was $\operatorname{dTB}\left(\mathrm{mm}^{2}\right)=16932.67 \mathrm{TL}$ $(\mathrm{mm})^{-0.819}$. The decrease in density was especially important in the early phases of the fish's life, and was slower in fishes longer than $150 \mathrm{~mm}$. There were differences between the covariances of the 2 curves ( $f=9.380, p>0.05$ ). These differences showed a greater TB density in $M$. barbatus than in $M$. surmuletus.

\section{Taste bud addition}

In the 2 species there were very significant post-settlement changes in the number of taste buds (nTB) of the barbels (Fig. 7), which increased throughout growth. In Mullus surmuletus the relationship is $\mathrm{nTB}=47.134 \mathrm{TL}(\mathrm{mm})^{1.238}$. Following this model the estimated number of TB increases from 8069 in a specimen with TL of $56 \mathrm{~mm}$ to 61228 in a 287



Fig. 6. Relationship between density of taste buds in the barbel surface (dTB or $\left.\mathrm{nTB} \mathrm{mm}^{-2}\right)$ and total length of fish $(\mathrm{TL}, \mathrm{mm})$ in Mullus surmuletus $(\ldots)$ and M. barbatus (-)

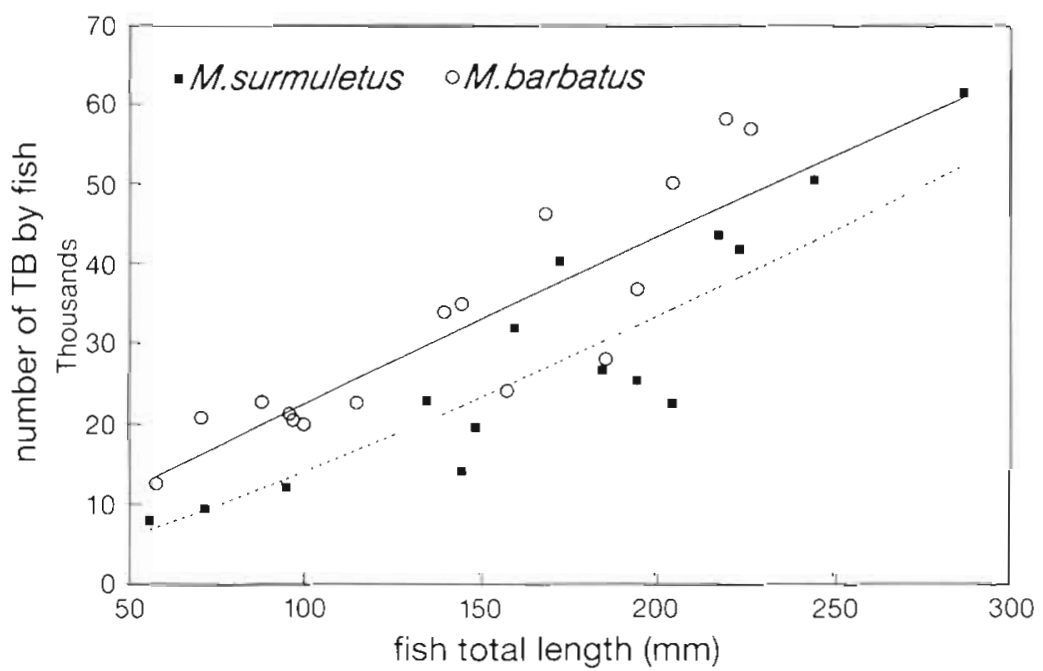

Fig. 7. Relationship between density of the total number of taste buds in the 2 barbels (nTB) and total length of fish (TL, mm) in Mullus surmuletus (...) and M. barbatus (-) 


\section{DISCUSSION}

\section{Significance of morphological differences}

The development of barbels has been associated with a compensatory mechanism in turbid waters, where the visual field is reduced (Davis \& Miller 1967) and the reactive distance of feeding in visual fish predators is decreased (Benfield \& Minello 1996). However, in the 2 species studied in this paper the greater proportional size of barbel surface is found in Mullus surmuletus, a species which is not abundant on muddy bottoms. The differences in barbel development may be associated with differences in the growth of the 2 species, without there being any clear physiological significance. $M$. surmuletus is characterised by greater body growth rate than $M$. barbatus (Renones et al. 1995, Sánchez et al. 1995). Similar results have been observed in river cyprinids of the genus Pseudobarbus (Cambray 1994), where species that live in clearer waters have proportionately longer barbels. Cambray (1994) suggests that in Pseudobarbus TB density may be more important than barbel length in locating food in its turbid environment.

In fresh-water Cyprinidae high external TB density has been associated with benthic and benthivorous species (Gomahr et al. 1992). A similar relationship is observed in the Mullidae species studied, which are selective predators of benthic invertebrates (Gharbi \& Ktari 1979, Guillén \& Martínez 1995). The 2 species studied show morphological and ecological similarities to benthivorous Cyprinids. Both groups have high chemoreceptor clensity in the barbels or in areas near the head, which provide high sensitivity to chemical stimulus (Gosline 1984, Gomahr et al. 1992, McCormick 1993, Lombarte \& Aguirre 1995). In Mullus barbatus mean density is $336 \mathrm{~TB} \mathrm{~mm}^{-2}$ and in $M$. surmuletus, $200 \mathrm{~TB} \mathrm{~mm}^{-2}$; in some benthivorous Cyprinidae studied by Gomahr et al. (1992), external TB densities in the gular region were between 285 and $297 \mathrm{~TB} \mathrm{~mm}^{-2}$

A higher number and density and a more complex structure of chemoreceptors in Mullus barbatus is related to a highor sensitivity of its barbels to chemical stimulus than in M. surmuletus (Caprio 1988, Gomahr et al. 1992). Since the barbels' function is are related to the process of searching for prey items (Gosline 1984), a greater sensitivity in $M$. barbatus could facilitate the location of prey in muddy bottoms, which are more turbid (Ros et al. 1985), where visibility is lower (Benfield \& Minello 1996), and where chemical stimuli are a more important source of information than in the rocky areas (Bardach \& Atema 1971).

Mullus barbatus has morphological characteristics (TB distribution forming larger groups, head shape and absence of colour in the fins) and ecological char- acteristics (muddy, turbid and low visibility bottoms) which differ from the other Mullidae studied. The morphological adaptation of the barbels could be related to other morphological trends of $M$. barbatus like the shape of its head, which is angular in profile, and the colourless dorsal fin (Hureau 1986). Gosline (1984) suggests that the head profile is an adaptation of the muscles involved in improving the water jet power used to agitate the bottom. The loss of colour in the dorsal fin is also related to a turbid bottom where the visual field is very limited.

Mullus surmuletus shows morphological characteristics (TB distribution isolated or forming small groups of 2 or $3 \mathrm{TBs}$, lengthened head profile, coloured dorsal fin) which are similar to those of other less specialised Mullidae such as Upeneus tragula, an inhabitant of clear surface waters (Gosline 1984, McCormick 1993)

In short, the 2 species of the genus Mullus, characterised by specialisation of feeding on benthic invertebrates, have adapted by evolution to different habitats, in accordance with the tendency to minimise competition and predation in species of common origin. The development of distinct sensorial structures, in this case the chemoreceptor organs in the barbels, played a fundamental role in this process of specific differentiation.

\section{Taste bud addition}

There is a significant post-embryonic increase in the number of taste buds in the barbels of the 2 species of the genus Mullus throughout their life. As estimates are available of the fish's age, based on study of the otoliths (Sánchez et al. 1983, Reñones et al. 1995) or modal length frequency analysis (Sánchez et al. 1995), and of the total number of taste buds, it is possible to determine an estimated average taste bud addition for the 2 species of Mullus studied. Depending on the method used to determined age, taste bud addition varies between 17.5 and $44.9 \mathrm{~TB} \mathrm{~d}^{-1}$ in $M$. surmuletus and between 19.4 and $51.84 \mathrm{~TB}^{-1}$ in $M$. barbatus. Bearing in mind that taste buds are made up of groups of sensory cells (Caprio 1988, McCormick 1993, Reutter 1994), the rate of cell addition must be greater. This rate is even greater in young specimens, as is indicated both by a negative allometric relationship between the number of TB and the length of the fish and by the greater TB density in immature fishes.

There have been descriptions of an increase in TB in the initial phase of life of the tropical Mullidae Upeneus tragula, which coincides with changes that take place during the settlement of the larvae on the bottom (McCormick 1993). That study showed that the increase is continuous throughout the fish's life, even after maturity (120 to $150 \mathrm{~mm}$ total length). The con- 
tinuous post-embryonic growth of chemoreceptor cells is comparable with that of other sensorial systems of teleost fish, as is the case for the photoreceptor layer and pigment epithelium of the retinas in Merluccius (Mas-Riera 1991) or for the mechanoreceptor ciliad cells of the endorgans of the inner ear of Astronotus ocellaris (Popper \& Hoxter 1984) and Merluccius merIuccius (Lombarte \& Popper 1994).

The significance of the increase in sensory cells throughout growth is unknown; nevertheless, some authors consider this increase to be related to a compensation of the sensorial structures in response to morphological and ecological changes in adult specimens. Some sensory abilities of adults, especially those connected with the discrimination and locating of sources of sensory stimuli (food sources, predators), are thus improved (Corwin 1983, Popper et al. 1988, MasRiera 1991, Lombarte \& Popper 1994). The fact that larger specimens of the same species can live in deeper waters (Suau \& Vives 1957, Recasens 1992, Reñones et al. 1995) supports the hypothesis that the increase in sensory cells is related to an increase in certain sensory abilities which compensate for the limitation of the visual field (Mas-Riera 1991, Lombarte \& Fortuño 1992, Lombarte \& Popper 1994) in such a way that throughout the life cycle of a species there is a wide distribution of resources.

Acknowledgements. This work was supported by EC projects MED92/009 and 1541/PCP. We especially thank L. Recasens and the director of the MEDITS project in Spain, L. Gil de Sola, for providing additional material used in this study. We are grateful to P. Sánchez, M. Demestre, P. A belló, L. Recasens and B. Morales-Nin for their valuable comments on the manuscript. We also thank J. M. Fortuño and J. Biosca for help with the SEM photographs.

\section{LITERATURE CITED}

Appelbaum J, Adron W, George SG, Mackie AM, Pirie BJS (1983) On the development of the olfactory and the gustatory organs of the Dover sole, Solea solea, during metamorphosis. J Mar Biol Assoc UK 63:97-108

Bardach JE, Atema J (1971) The sense of taste in fishes. In: Beidler LM (ed) Handbook of sensory physiology. Springer-Verlag, Heidelberg, p 293-336

Benfield MC, Minello TJ (1996) Relative effects of turbidity and light intenstty on reactive distance and feeding of an estuarine fish. Environ Biol Fish 46:211-216

Blaxter JHS (1988) Sensory performance, behavior and ecology of fish. In: Atema J, Fay RR, Popper AN, Tavolga WN (eds) Sensory bıology of aquatic anımals. SpringerVerlag, New York, p 203-232

Bougis P (1952) Recherches biométriques sur les rougets (Mullus barbatus L., Mullus surmuletus, L.). Arch Zool Exp Gén 89:57-174

Cambray JA (1994) Effects of turbidity on the neural structures of two closely related redfin minnows, Pseudobarbus afer and $P$. asper, in the Gamtoos River system. South Africa. S Afr Tydskr Dierkd 19:126-131
Caprio J (1988) Peripheral filters and chemoreceptor cells in fishes. In: Atema J, Fay RR, Popper AN, Tavolga WN (eds) Sensory biology of aquatic animals. Springer-Verlag. New York, p 313-332

Corwin JT (1983) Postembryonic growth of the macula neglecta auditory detectorn the ray, Raja clavata: continual increases in hair cell number, neural convergence, and physiological sensitivity. J Comp Neurol 217:345-356

Davis BJ, Miller RJ (1967) Brain patterns in minnows of the genus Hybopsis in relation to feeding habits and habitat. Copela 1967:1-39

Garcia-Rubies A, Macpherson E (1995) Substrate use and tomporal pattern of recruitment in juvenile fishes of the Mediterranean littoral. Mar Biol 124:35-42

Gharbi H, Ktan MH (1979) Régime alımentaire des rougets (Mullus barbatus Linnaeus, 1758 et Mullus barbatus Linnaeus, 1758) du golfe de Tunis. Bull Inst Natl Sci Tech Océanogr Pêche Salammbô 6:41-52

Gomahr A, Palzenberger MM, Kotrschal K (1992) Density and distribution of external taste buds in cyprinids. Environ Biol Fish 33:125-134

Gosline WA (1984) Structure, function and ecology in the Goatfishes (Family Mullidae). Pacif Sci 38:312-323

Guillén JE, Martínez N1 (1995) Mullus surmuletus (L. 1758) decapoda selective predation. Rapp Comm Int Mer Medit $34: 244$

Huber R, Rylander MK (1992) Brain morphology and turbidity preference in Notropis and related genera (Cyprinidae, Teleostei). Environ Biol Fish 33:153-165

Hureau JC (1986) Mullidae. In: Whitehead PJP, Bauchot ML, Hureau JC, Nielsen J, Tortonese E (eds) Fishes of the North-eastern Atlantic and the Mediterranean, Vol 2 UNESCO, Paris, p 877-882

Kotrschal K (1992) Quantitative scanning electron microscopy of solitary chemoreceptor cells in cyprinids and other teleosts. Environ Biol Fish 35:273-282

Kotrschal K (1995) Ecomorphology of solitary cell system in fish: a review. Environ Biol Fish 44:143-155

Livingston ME (1987) Morphological and sensory specializations of five New Zealand flatfish species, in relation to feeding behaviour. J Fish Biol 31:775-795

Lombarte A, Aguirre H (1995) Morphological features of the barbels in Mullus surmuletus, L., 1758 and M. barbatus, L., 1758. Rapp Comm Int Mer Medit 34:248

Lombarte A, Fortuño JM (1992) Differences in morphological features of the sacculus of the inner ear of two hakes (Merluccius capensis and $M$. paradoxus) inhabits from different depth of sea. J Morphol 213:97-107

Lombarte A, Popper AN (1994) Quantitatıve analyses of postembryonic hair cell addition in the otolithic endorgans of the inner ear of the European hake. Merluccius merluccius (Gadiformes, Teleostei). J Comp Neurol 345:419-428

Mas-Riera J (1991) Changes during growth in the retinal structure of three hake species, Merluccius spp. (Teleostei: Gadiformes), in relation to their depth distribution. J Exp Mar Biol Ecol 152:91-104

McCormick MI (1993) Development and changes at settlement in the barbel structure of the reef fish, Upeneus tragula (Mullidae). Environ Biol Fish 37:269-282

Norton SF, Luczkovich JL, Motta PJ (1995) The role of ecomorphological studies in the comparative biology of fishes. Environ Biol Fish 44:287-304

Popper AN (1977) A scanning electron microscopic study of the otolithic organs of the bichir (Polypterus bichir) and shovel-nose sturgeon (Scaphurhynchus platonynchus). J Comp Neurol 181:117-128

Popper AN, Hoxter B (1984) Growth of a fish ear. Iyer. Quan- 
titative analysis of sensory hair cell and ganglion cell proliferation. Hear Res 15:133-142

Popper AN, Rogers PH, Saidel WM, Cox M (1988) Role of the fish ear in sound processing. In: Atema J, Fay RR, Popper AN, Tavolga WN (eds) Sensory biology of aquatic animals. Springer-Verlag, Nesw York, p 687-710

Recasens L (1992) Dinàmica de poblacions y pesqueria de lluç (Merluccius merluccius) al Golf de Lleó y la Mar Catalana. PhD thesis, Universitat de Barcelona

Reñones O, Massuti E, Morales-Nin B (1995) Life history of the red mullet Mullus surmuletus from the bottom-trawl fishery off the Island of Majorca (north-west Mediterranean). Mar Biol 123:411-419

Reutter K (1994) Comparative aspects of vertebrate taste cell microvillar structures. Adv Biosci 93:3-9

Ros J, Romero J, Ballesteros E, Gili JM (1985) Diving in blue

This article was submitted to the editor water. The benthos. In: Margalef $\mathrm{R}$ (ed) Key environments: Western Mediterranean. Pergamon Press Ltd, Oxford, p 233-295

Sánchez P, Alvarez F, de Ranieri S, Sartor P (1995) Evaluation and analysis of the interaction of fishing gears in the demersal fisheries of Western Mediterranean. Final Report, EC Programme Studies in the Fisheries Sector MED92/009 (mimeo)

Sánchez P, Morales-Nin B, Martín P (1983) The mullets (Mullus surmuletus L. 1758, Mullus barbatus L. 1758) of the Catalan coast: biological and fishing aspects. Int Counc Explor Sea Comm Meet (Demersal Fish Comm) 27. $1-19$

Suau P, Vives F (1957) Contribución al estudio del salmonete de fango (Mullus barbatus L.) del Mediterráneo occidental. Invest Pesq 9:97-118

Manuscript first received: October 28, 1996

Revised version accepted: February 14, 1997 